\title{
Freedom of Expression in Malaysia: Compatibility with the International Human Rights Standard
}

\author{
Saidah Fasihah Binti Che Yussoff ${ }^{\mathrm{a}, 1, *}$, Rohaida Nordina, ${ }^{\mathrm{a}, 2}$ \\ ${ }^{a}$ Faculty of Law, Universiti Kebangsaan Malaysia, Malaysia. \\ ${ }^{1}$ sfasihahkhas@gmail.com*, ${ }^{2}$ rohaidanordin@ukm.edu.my \\ * corresponding author
}

\section{ARTICLE INFO}

Article history

Received: February 5, 2021

Revised: June 7, 2021

Accepted: July 1, 2021

Keywords

Expression;

Freedom;

Expression;

Human Right;

\section{ABSTRACT}

Malaysia is likely to introduce new laws on freedom of information. However, the important questions are whether the said laws are effective and will have enough bite with the public looking forward to opening government policy. Freedom of information has developed under international human rights law as the right to freedom of expression, including the freedom to seek, receive and impart knowledge and ideas through media, regardless of any frontier. This study aims to examine freedom of expression under the international realm, scrutinize the said freedom in the Malaysian legal framework, and discuss the proposed enactment of freedom of information laws in Malaysia in conformity with international human rights law. This research uses the qualitative research method. This study concludes that freedom of information in Malaysia is severely impeded by the enforcement of the Official Secret Act. This study calls for the repeal or amendment to the Act in conformity with international standards.

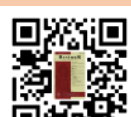
This is an open access article under the CC-BY 4.0 license.

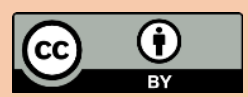

\section{Introduction}

The right to freedom of opinion and expression is recognized under international human rights law as a fundamental right of individuals. It is also recognized as a fundamental right of citizens in ensuring the transparency of the government. Under such freedom, everyone can hold opinions without interference and seek, receive, and impart information and ideas through any media and regardless of any frontier. According to this right, every citizen is entitled to look for and acquire any information on the government's activities that count for its accountability as a way to combat corruption (O'Shannassy, 2013). For this specific context, scholars refer to freedom of expression as the right to freedom of information. Thus, the right to freedom of information can impose changes in the relationship between the State and its people (Saravanamuttu \& Mohamad, 2020).

Right to information entitles the right holder to demand government information from the state, a duty-bearer on how the state delivers their policy and practice. It requires the state to explain and justify its decision-making on government spending and policymaking for the citizens to democratically participate in the political and economic development of the State. It changes the balance of power and creates a liability on the part of the State (Dettman \& Gomez, 2020). In addition, access to government-held information is essential for various reasons for democratic control of the exercise of the government authority, for the public to verify decisions made by the administration, 
and for personal data protection. Every individual, including the convict of a criminal offense, should have the right to ascertain their data held by the government (Saravanamuttu \& Mohamad, 2020).

In Malaysia, the right of speech and expression is one of the fundamental liberties under Article 10 of Malaysia Constitution. Even then, there is no explicit provision under the constitution on the right to freedom of information. Any request for access to government information can be denied under the Official Secret Act 1972. The issue, therefore, concerns the obligation of the government to protect the freedom of information. This study aims to examine the right to freedom of information under international human rights law, scrutinize the right to freedom of information in the Malaysian legal framework, and discuss the proposed enactment of the release of information laws in Malaysia in conformity with the international human rights law.

\section{Research Methods}

This research uses a qualitative method to collect and analyze data. The collected data were from primary and secondary sources relevant to this research. The data analysis then adopted content analysis and comparative analysis is methodologies (Rosidah, 2020). Additionally, this research also adopts comparative legal analysis and a doctrinal approach. The data analysis is mainly on the right to freedom of information in international law, such as treaties, declarations, and cases in the Malaysian legal framework (Ichlas, 2020).

\section{Discussion}

\subsection{Freedom of Information as a Basic Human Right Under International Law}

The right to freedom of people's information encompasses two aspects: ownership of the governed people to access information possessed by the governing state. The data must always be made known to the public despite non-request as a matter of public interest (Zhang et al., 2017). These two main aspects of freedom of information have been confirmed in international and regional treaties. Article 19 of the Universal Declaration of Human Rights 1948 (UDHR) provides freedom of opinion and expression encompasses freedom of information:(Tapsell, 2013)

\section{"Everyone has the right to freedom of opinion and expression; this right includes freedom to hold opinions without interference and to seek, receive and impart information and ideas through any media and regardless of frontiers."}

The freedom of expression is also guaranteed in Article 19 (2) of the International Covenant on Civil and Political Rights 1966 (ICCPR). The release of the word under the ICCPR entails the right to information save for restrictions under the law or limitations necessary to protect the rights or reputations of other persons or the state's national security or public order, public health, or morals. Meanwhile, Article 25 of ICCPR provides the right of the citizens to participate in the conduct of public affairs (Weiss, 2013) :

"Every citizen shall have the right and the opportunity, without any of the distinctions mentioned in Article 2 and without unreasonable restrictions to take part in the conduct of public affairs, directly or through freely chosen representatives."

To elaborate the importance of the right to freedom of information to the right of the people to participate in governmental affairs, the Human Rights Committee of ICCPR in Robert W. Gauthier v Canada (Communication No. 633/1995) decides that every citizen through the medium of media reports are guaranteed complete access to the activities of the state representatives and the citizens are free to convey the information and to express their opinions on the matter. In Mavlonov and Saadi v Uzbekistan (Communication No. 1334/2004), complaints are derived from the refusal of the state to re-register a local newspaper. The Human Rights Committee rules that the right to freedom of expression under Article 19 of the ICCPR has been violated so that the right of the journalist to disseminate information and the right of the public to receive the information via newspaper has been denied the State (Steele, 2013).

The Committee notes that the public has a right to receive information as a corollary of the specific function of a journalist and/or editor to impart information. In Konstantin Zhukovsky v Belarus (Communication 2955/2017), the complainant, a freelance journalist, is sanctioned to film residents 
and distribute video materials via the internet and through foreign satellite channels on six separate incidents without a valid accreditation in violation of the law on mass media. The Human Rights Committee concludes that the right of the complainant under Article 19 (2) of the ICCPR has been violated in the absence of any explanation by the State Party (Belarus) nor the domestic court as to how the restrictions are justified under the conditions of necessity and proportionality as set out in Article 19 (3) of the ICCPR and whether the administrative fines imposed, even if based on law, are necessary, proportionate and in compliance with any legal purposes listed in mentioned provisions (Tapsell, 2013).

It is observed that freedom of information is acknowledged under the ICCPR to form freedom of opinion and expression. In General Comment No.10, it is affirmed that protection of the right to freedom of expression includes not only freedom to "impart information and ideas of all kinds" but also the freedom to "seek" and "receive" them "regardless of frontiers" and in whatever medium, "either orally, in writing or in print, in the form of art, or through any other media of his choice"(Daud, 2014). It is further affirmed that the restrictions on the exercise of freedom of expression may only be imposed by the State Party subject to the two conditions under Paragraph 3, the limits must be provided by law, and they are necessary for pursuant of any of legitimate interests in subparagraphs (a) and (b) of Paragraph 3 However, the United Nations (UN) special rapporteur on freedom of opinion and xpression stresses that the right to freedom of information is independent of the other privileges. It is a necessary right of democratic societies. Instead, every other liberty and freedom will have no effect when people have no access to information.

The right to freedom of information is also fundamental in exercising other human rights, such as the right to development, democracy, and the right to a clean environment. Dissemination of comprehensive information by the government will empower the citizen to seek remedy in case of any governmental interference or violation with the exercise of their civil, political, economic, and social rights in particular to the people living in extreme poverty, the minorities, and other vulnerable groups. Every citizens and resident own the information held by the government that it should always be made available for access. The right to freedom of information to includes the right for proactive dissemination (seek), the right for reactive dissemination (receive), and the right to re-use and redistribute the received information (impart) (Khairuldin et al., 2017).

The UN special rapporteur on freedom of opinion and expression in 2000 has endorsed a set of principles on the features of freedom of information regime which have been developed by the nongovernmental organization called Article 19. The guides are known as The public's right to know: principles on freedom of information legislation (Article 19 Principles) serves as UN guidelines for national and international law on the right to freedom of information. The Article 19 principles have no legal effect on the State Party of the ICCPR. Nevertheless, it represents the conformity of international and national legal standards, State practice, and general principle of law on the citizen's right to freedom of information.

The fundamental principles on the freedom of information cover full disclosure, obligation to publish, promotion of open government, the limited scope of exceptions, processes to facilitate access, costs, open meetings, disclosure takes precedence and protection for whistleblowers. In brief, features of the freedom of information under the Article 19 Principles involve the following (Daud \& Zulhuda, 2020):

1. The maximum disclosure of information held by government and its branches to any person and member of the public.

2. Despite no request, the public authorities are compelled to constantly publish essential information in lists and registers.

3. The principle of open government must be operative, and in a way to promote the guide, the government must impose penalties for any wilful act of the public authorities to deny access to information.

4. Exceptions to the access should be strictly limited to situations that warrant the risk of harm.

5. Every process on the request must be expeditious, and in case of refusal, a review by an independent body should be made available. 
6. The cost of access should not exceed the reasonable amount.

7. The right to information should also apply to all meetings of public bodies.

8. Secrecy law which violates the principle of maximum disclosure should be amended or abolished.

9. The law should protect individuals who release information on wrongdoings or whistleblowers.

In Robert W. Gauthier v Canada (Communication No. 633/1995), the Human Rights Committee comments on the requirement of the state's restriction to the public's right to freedom of information in which the right by itself must not impede the performance of public authorities' functions and duties. The state can impose restrictions on the access, which must be compatible with the provisions of the convention. The Article 19 Principles set out a three-part test to justify the limits the information must connect to the legitimate aim listed in the law, disclosure of the data must threaten to cause substantial harm to that aim, and the damage to the objective must be more significant than the public interest in having the information (Daud, 2014).

It is provided under Article 29 of UDHR, Article 19 (3) of the ICCPR, and Article 10 (2) of the European Convention on Human Rights 1950 (ECHR) that the legitimate aims for the restrictions may concern with the preservation of the state's security, public order, health or morals, protection of rights or reputation of others and safeguarding of the power and independence of the judiciary. Nondisclosure of information can never be justified to protect the government from embarrassment or wrongdoing (Weiss, 2013). Some matters must be presumed to be a matter of public interest, such as criminal convictions, infringement of human rights or humanitarian law, corruption, and misuse of public authorities, public safety, and environmental damage. The three-part test must be applied strictly on a case-by-case basis that although the restrictions on the access of information may be compatible with Paragraph 3 of Article 19 of the ICCPR, they also must be justified on the basis that the disclosure of the data will threaten to cause substantial harm to any of the legitimate aims and the said harm outweighs the public interest in having the information made public (Zhang et al., 2017).

In regional instruments, Article 10 of ECHR guarantees the right to freedom of information under the freedom of expression and freedom to hold opinions, Article 13 of American Convention on Human Rights 1969 (ACHR), and Article 9 of African Charter on Human and Peoples' Rights 1976 (African Charter). An explicit and elaborated right to freedom of information is enumerated under the Council of Europe Convention on Access to Official Documents 2009. In its preamble, the Convention explicitly recognizes that access to official documents supplies information to the public to assist the public to embody their personal opinion on the state and public authorities. The right by itself promotes the integrity, efficiency, effectiveness, and accountability of public authorities. Thus, under Article 2 of the Council of Europe Convention on Access to Official Documents 2009, everyone is entitled to access official documents regardless of any ground of such request (Daud, 2014).

The right to freedom of information has been incorporated in various countries' constitutions, and at least 59 countries have expressed such ownership in their respective constitutions. There is also an increasing record number of countries worldwide that have enacted legislation giving effect to the right to freedom of information, for example, India, Japan, and South Africa. Sweden is the first country to pass the freedom of information law vides Freedom of Press Act 1766. In Southeast Asia, only Thailand, Indonesia, Philippines, and Vietnam have dedicated space of information laws. Official Information Act 1997 (Thailand), Public Information Disclosure Act 2008 (Indonesia), Executive Order No. 2, s. 2016 (Philippines), and Law on Access to Information 2016 (Vietnam). In Cambodia, a draft law on access to information is made public in February 2019 (Daud \& Zulhuda, 2020).

\subsection{Freedom of Information in Malaysia Legal Framework}

Freedom of information is not explicitly anchored as a result of freedom of speech and expression under Article 10 (1) of the Malaysia Constitution, which provides that "every citizen has the right to freedom of speech and expression." Malaysia is also not a State Party to the ICCPR. Thus, the treaty does not create legal obligations on Malaysia without its consent under Article 34 of the Vienna Convention on the Law of Treaties 1969. On the other hand, the UDHR has no binding legal effect as some of its provisions are not in conformity with Malaysia's existing general principles and rules 
(Vithiatharan \& Gomez, 2014). It was ruled in the case of Merdeka University Berhad v Government of Malaysia (1981) that the UDHR is "merely a statement of principles devoid of any obligatory character and is not part of our municipal law." In the case of Mohamad Ezam bin Mohd Noor v Ketua Polis Negara \& Other Appeals (2002) 4 MLJ 449, Norma Yaakob J. had this to say (Tham, 2017):

\begin{abstract}
"It must be borne in mind that the 1948 Declaration is a resolution of the General Assembly of the United Nations and not a convention subject to the usual ratification and accession requirements for treaties. By its very title it is an instrument which declares or sets out statement of principles of conduct with a view to promoting universal respect for and observance of human rights and fundamental freedoms. Since such principles are only declaratory in nature, they do not, I consider, have the force of law or binding on Member States. If the United Nations wanted those principles to be more than declaratory, they could have embodied them in a convention or a treaty to which Member States can ratify or accede to and those principles will then have the force of law."
\end{abstract}

Even Malaysia is a signatory to the ASEAN Declaration of Human Rights (ADHR), which contains freedom of information under Article 23 and a party to the Commonwealth when the Commonwealth Heads of Government approved the 1999 resolution on the right to freedom of data as a legal and enforceable right, the protection of such right is still indeterminate. Malaysia is not under any legal obligation to guarantee the right to freedom of information provided under these soft laws as the legislative and the judiciary decided (Teh, 2002). Malaysian Court is reluctant to introduce positive obligations and, in particular, a responsibility of the state to provide access to information in the context of Article 10 of Malaysia Constitution. Access to information is treated as a privilege, not a right. In Haris Fatillah v Malaysia Election Commission [2017], the case revolves around a voter's petition to the Election Commission for all information regarding the delimitation of the constituency. The appellant invoked his freedom of information in the exercise of freedom of expression on public or political interest. The Court of Appeal in 2017 held that (Tapsell, 2013) :

"Unlike India, we do not have specific statutes such as the Right to Information Act, 2005, which
provides elaborate and comprehensive matters on the right to information. Neither do we have similar
freedom of opinion and expression under section $2(b)$ of the Canadian Charter of Rights and
Freedoms, which permits access to information under section $2(b)$. But what we take pride in and
observe is our Constitution which stands in its own right, and it is, in the end, the wording of our
Constitution itself that is to be interpreted and applied, and the extraneous principles of other
Constitutions can never override this wording". that:

Earlier in 2010, the Federal Court in Sivarasa Rasiah v Malaysia Bar Council \& Anor [2010] ruled

"Article 10 contains certain express and, by interpretive implication, other specific freedoms. For example, the freedom of speech and expression are expressly guaranteed by art 10(1). The right to be derived from the express protection is the right to receive information, which is equally guaranteed: See Secretary, Ministry of Information and Broadcasting, Government of India v Cricket Association of Bengal AIR 1995 SC 1236."

Even though the attention was brought to Sivarasa Rasiah's case by the appellant in Haris Fatillah's case, the Court of Appeal has refused to consider the interpretative principle of Article 10 made by the Federal Court in Sivarasa Rasiah's case. In support of its decision, the Court of Appeal cited the case of Loh Kooi Choon v Government of Malaysia [1977] and Public Prosecutor v Kok Wah Kuan [2008], which hold the judgment that "the ultimate touchstone of constitutionality is the constitution itself and not any general principle outside it" and "whatever may be said of other constitutions, they are ultimately of little assistance" (Nawang, 2013).

In some countries, the right to freedom of information is accomplished by the court's interpretation of existing constitutional rights when the constitution does not refer to the right to freedom of information. In Kaneko v Japan Keishu 1490 (Sup. Ct. Nov 26, 1969), the Japanese Supreme Court ruled that the right to information is protected by Article 21 of the Japan Constitution, which does guarantee the freedom of assembly, organization, speech, and the press, together with any other form of expression. In S.P. Gupta v Union of India A.I.R. 1982 S.C. 149, 234, the Supreme Court has set a precedent that the right to information forms an essential element of the freedom of expression under Article 19 of the Indian Constitution. The South Korea Constitutional Court, in the case of Forest Survey Inspection Request (1989) declared that the fulfillment of the plaintiff's freedom of expression 
in Article 21 of the South Korea Constitution entailed the free assimilation of ideas, together with the free collection and analysis of information (Mohd Sani, 2018).

In the case of Ontario (Public Safety and Security) v Criminal Lawyer's Association [2010], the Canadian Supreme Court concluded that Section 2 (b) of the Canadian Charter of Rights and Freedoms on freedom of opinion and expression in itself permits the right to information. The Court further held that "to show that access would further the purpose of Section 2 (b), the claimant must establish that access is necessary for the meaningful exercise of free expression on matters of public or political interest" (Rehman \& Shahid, 2018). The freedom of information in Japan, India, South Korea, and Canada is constitutionally anchored when the Court is willing to derive such right employing interpretation of recognized rights (Zhang et al., 2017). Regrettably, the Court of Appeal in the case of Haris Fatillah has opted to restrict the wording of the constitution, in particular, Article 10, even though the Court has the opportunity to confirm the interpretative principles laid down by the Federal Court in Sivarasa Rasiah's case and court decisions of other countries. It is to be concluded from the judgment in Haris Fatillah's case that the right to freedom of information can only be recognized under any federal legislation (Singh \& McKleroy, 2011). Therefore, there is a need for the federal government to enact the law which confers the right to freedom of information or to amend the Malaysian Constitution to include the right to freedom of data as a result of freedom of speech and expression under Article 10 (Khairuldin et al., 2017).

\subsection{Enactment of Freedom of Information Law in Conformity with International Human Rights Law}

There are two State laws on freedom of information in Penang and Selangor, namely Penang Freedom of Information Enactment 2010 and Freedom of Information (State of Selangor) Enactment 2011. These State enactments on freedom of information provide access to information made by every department of the State Government upon application of request from any person (Daud, 2014). Section 2 (1) of Penang Enactment defines "document" to include "any files, facts, memoranda, figures, diagrams, statistic, maps, photographs, drawings, computer print-outs, correspondence, file noting, electronics and computer data, data on the collection and inspection of samples or any other recorded information, regardless of its form (whether in writing, oral, digital, magnetic, photographic, machine-readable or other forms), source, date of creation, or official status, whether or not it has been collated, whether or not it was created by the body that holds it and whether or not it is classified" and "information" means "any document made by any State Government Department but does not include information in documents that are exempted" and "department" refers to "any State Government Departments, State Statutory Bodies and Local Authorities"(Tham, 2017).

Section 2 of Selangor Enactment defines "document" to include "any matter expressed, described, or howsoever represented by any means whatsoever, upon any substance, material, thing or article and any matter embodied, produced, reproduced or transmitted in, through or to a disc, tape, film, sound track, recording (whether audio, visual or any other type of recording) or any other form or medium whatsoever" and "information" means "any information in whatever form including any documents made, amended, modified, transformed, obtained, received, held or kept in the custody or control or any department or to which any department has reasonable access" and "department" refers to "any department of the State Government, local government and any entity which is owned or wholly controlled by the State Government"(Steele, 2013).

To compare, application to the access of information under Penang Enactment is less stringent than Selangor Enactment. Under Section 6 (2) of Selangor Freedom of Information Enactment, the application for information must provide the reason and purpose of the application (Rasiah et al., 2009). There will be the arrest of the person who uses the obtained information contrary to the specified reason or purpose as provided under Section 18 (1) of Selangor Freedom of Information Enactment. However, both enactments impose no mandatory periodic publication of information on the public authorities. Any access to information excludes any document classified under the Official Secret Act under Article 75 of the Federal Constitution. The purposes or aims of the restriction to information entrance are laid down in Section 11 of Penang Freedom of Information Enactment and Section 14 of Selangor Freedom of Information Enactment (Miles \& Croucher, 2013). The guideline on the balance of harm between State interest and public interest is also explicitly provided under Section 11 (2) of Penang Freedom of Information Enactment and Section 15 (1) of Selangor Freedom of Information Enactment (Li \& Cheong, 2017). 
The state enactments portray a positive attitude of the government towards recognizing the right to freedom of information to uphold an open government policy. However, the release of information under the state enactments is far from achieving its objective and purpose when the laws are superseded by the federal law of Official Secret Act 1972. The government authorities use the Official Secret Act as a bulwark to deny any public access to government information. To illustrate, in the case of Malaysia Trade Union Congress \& Ors v Menteri Tenaga, Air dan Komunikasi \& Anor [2014], the Malaysian Trade Union Congress (the MTUC) applied to the Minister for a copy of the concession agreement and the audit report justifying the $15 \%$ increase in water tariffs. However, the Minister refused the MTUC's right to access the said documents. The MTCU sought a declaration of their right to access the documents. The Federal Court ruled that the audit report had been tabled before and deliberated by the Cabinet in its meeting. Therefore, it was an official secret document under the Official Secret Act, and the Minister was prevented from disclosing it (Lee, 2012).

1. On several occasions, the government has abused the law to avoid embarrassment and conceal corruption. A few examples of the uses of the Official Secret Act by the public authorities could be listed as follows: Royal Malaysia Police has denied NGO Women's Aid Organisation (WAO) access to its 2010 statistics on sexual crimes against women and children on the reason the document has been classified as a secret document under the Official Secret Act on the instruction of Inspector-General of Police.

2. Nathaniel Tan, a member of the political opposition party, has been arrested under Section 8 of the Official Secret Act for possession of documents linked to the alleged involvement of Deputy Minister of Internal Security in corruption.

3. Rafizi Ramli, a member of Parliament, is convicted under the Official Secret Act for exposing a page of the 1 Malaysia Development Bhd (1MDB) audit report.

4. The final 1MDB audit report has been classified under the Official Secret Act to prevent information leaks. The report prepared by the National Audit Development is alleged to have been tempered to avoid any civil or criminal action against the former Prime Minister.

Even though it has been acknowledged that the Official Secret Act is vulnerable to abuse, in 2018, the Prime Minister, Mahathir Mohamad, as he then was, has insisted the law stay. He has regarded the problem of abuse as lies with the previous government, not with the law itself. In his words, the law is not perfect. There are things we must keep secret. For example, if we tell everything we discussed in the Cabinet, a lot of us will be hammered. Following the three-part test, the law should provide a substantive balance between the state interest and the public interest. Any restriction on the public right must be reasonably justified and listed explicitly in the law (Nawang, 2013). Therefore, for the secrecy law to stay, the issue concerns whether the restriction to the freedom of information under the Official Secret Act can be justified to be necessary to protect legitimate aim according to the three-part test. Section 2 of the Official Secret Act defines "official secret" to include the following (Hutchinson, 2014):

\section{"Any document specified in the Schedule and any information and material relating to it and includes any other official document, information, and material as may be classified as "Top Secret," \\ "Secret," "Confidential," or "Restricted," as the case may be, by a Minister, the Menteri Besar or Chief Minister of a State or such public officer appointed under section $2 B$ ".}

The Schedule of the Official Secret Act specifies a list of official secret documents, which are among other cabinet documents, State Executive Council documents, and documents relating to national security and international relations. Following the definition in Section 2 of the Official Secret Act, in addition to the specified documents, any other documents may be classified as official secret by the designated authorities under Section 2B of the Official Secret Act. The extensive definition of the official secret document, together with the unfettered power of the references to mark the confidentiality of any documents, have rendered almost every government documents and information to be privileged and confidential (Hamilton-Hart, 2017). There is no guideline prescribing the manner of classifying the information, documents, or any other material. Therefore, it is submitted that the Official Secret Act has blocked any public access to the government official documents, whether it is for national security or public order or to protect the government from embarrassment or wrongdoing. 
The restrictions under the Act without legitimate aims have failed to satisfy the three-part test and comply with the international law standard (Gomez \& Lafaye De Micheaux, 2017).

The secrecy law has also, in effect, discouraged any disclosure of information by the whistleblower. Section 6 of the Whistleblower Protection Act 2010 provides that a person can disclose wrongdoing to the enforcement authority subject to the disclosure is not prohibited by any written law. Should the exposure be prevented under the law, such a person would not be entitled to the Whistleblower Protection Act and would likely face conviction under the Official Secret Act (Gomez, 2009). As a result of the existing provision, it is almost impossible to expose any wrongdoing of public officials and governmental bodies when a substantial amount of government documents are covered as official secrets under the Official Secret Act. It is also unfortunate that the government agencies invoke the Official Secret Act to refuse any request for public documents by the Human Rights Commission (SUHAKAM). Thus the law has impeded the function of SUHAKAM under Section 4 (1) of the Human Rights Commission of Malaysia Act 1999 to advise and assist the government (Gomez, 2016).

Should any federal legislation on the freedom of information be enacted in the future, the effectiveness of the said law will be bereft by the enforcement of the Official Secret Act. The Official Secret Act is an antithesis to the spirit of freedom of information law enumerated under Article 19 Principles (Khairuldin et al., 2017). Therefore, the Official Secret Act ought to be repealed or amended to restrict the classification of official secret documents and clarify the legitimate aims that justify the restriction on the free access of any government information. The freedom of information law must be enacted to provide the public's most complete freedom and rights to access government documents and information. The restriction of such request must be expressly listed in the law. There shall also be an imposition of legal obligation on public authorities to provide periodic publication of information (Poullet, 2011).

\section{Conclusion}

Freedom of information is a recognized human right as being a result of freedom of speech and expression. International human rights instruments require the states to promote and protect the right of individuals to seek, receive and impart information and ideas through any media and regardless of the frontier. The previous discussion demonstrates that the state may impose legitimate restrictions on the freedom of data when disclosing information causes a risk of harm. The regulation, however, must be applied strictly under the three-part test. In Malaysia, freedom of information is not constitutionally acknowledged as fundamental liberty under Part II of the Constitution. Freedom of information in Malaysia is impeded by the enforcement of the Official Secret Act. This colonial law is deemed to be no longer relevant as it promoted secrecy among government agencies for decades. It is high time for the government to finally recognize the right of the public to know whatever information is held by the government, which will significantly affect their enjoyment of other rights. The Official Secret Act should be repealed or amended to be compatible with international standards. The Whistleblower Protection Act should also be amended to facilitate disclosing any wrongdoing of public officials or government bodies. To legally recognize the freedom of information and impose the public authorities' obligation to disseminate the information, Malaysia should enact a comprehensive law following the international standards. Finally, for the fundamental freedom of data to be maximally effective, its very existence and exercise must be known to the public and civil servants.

\section{References}

Daud, M. (2014). Wild speculations on the missing flight MH370: Balancing online expression and content regulation in Malaysia. International Conference on Law, Policy and Social Justice 2014, 3(September), 0-10. https://doi.org/10.13140/RG.2.1.2443.7287

Daud, M., \& Zulhuda, S. (2020). Regulating the spread of false content online in Malaysia: Issues, challenges and the way forward. International Journal of Business and Society, 21(S1), 32-48, available at: Google Scholar.

Dettman, S., \& Gomez, E. T. (2020). Political financing reform: Politics, policies and patronage in Malaysia. Journal of Contemporary Asia, 50(1), 36-55. 
https://doi.org/10.1080/00472336.2019.1571218

Gomez, E. T. (2009). The rise and fall of capital: Corporate Malaysia in historical perspective. Journal of Contemporary Asia, 39(3), 345-381. https://doi.org/10.1080/00472330902944404

Gomez, E. T. (2016). Resisting the fall: The single dominant party, policies and elections in Malaysia. Journal of Contemporary Asia, 46(4), 570-590. https://doi.org/10.1080/00472336.2016.1192214

Gomez, E. T., \& Lafaye De Micheaux, E. (2017). Diversity of southeast Asian capitalisms: Evolving state-business relations in Malaysia. Journal of Contemporary Asia, 47(5), 792-814. https://doi.org/10.1080/00472336.2017.1322629

Hamilton-Hart, N. (2017). Opting for openness: Capital mobility and monetary sterilisation in Malaysia. Journal of Contemporary Asia, 47(2), 171-198. https://doi.org/10.1080/00472336.2016.1257045

Hutchinson, F. E. (2014). Malaysia's federal system: Overt and covert centralisation. Journal of Contemporary Asia, 44(3), 422-442. https://doi.org/10.1080/00472336.2013.878374

Ichlas, R. I. (2020). Questioning the Independence of Media Coverage in the 2019 Elections. Jurnal Bestuur, 8(1), 53-59. https://doi.org/10.20961/bestuur.42725

Khairuldin, W. M. K. F. W., Anas, D. I. W. N. I. W. N., Ibrahim, I., \& Fauzi, N. (2017). Freedom of speeches by mufti according to Islam: Implication to fatwa in Malaysia. International Journal of Academic Research in Business and Social Sciences, 6(12), 141-151. https://doi.org/10.6007/ijarbss/v6-i12/2581

Lee, H. A. (2012). Affirmative action in Malaysia: Education and employment outcomes since the 1990s. Journal of Contemporary Asia, 42(2), 230-254. https://doi.org/10.1080/09500782.2012.668350

Li, R., \& Cheong, K. C. (2017). Huawei and ZTE in Malaysia: The localisation of Chinese transnational enterprises. Journal of Contemporary Asia, 47(5), 752-773. https://doi.org/10.1080/00472336.2017.1346697

Miles, L., \& Croucher, R. (2013). Gramsci, Counter-hegemony and labour union-civil society organisation coalitions in Malaysia. Journal of Contemporary Asia, 43(3), 413-427. https://doi.org/10.1080/00472336.2013.775754

Mohd Sani, M. A. (2018). Islam and freedom of religious expression in Malaysia. The Journal of Social Sciences Research, SPI6, 1218-1224. https://doi.org/10.32861/jssr.spi6.1218.1224

Nawang, N. I. (2013). Political blogs and freedom of expression : A comparative study of Malaysia and the United Kingdom, available at: Google Scholar.

O'Shannassy, M. (2013). More talk than walk? UMNO, "new politics" and legitimation in contemporary Malaysia. Journal of Contemporary Asia, 43(3), 428-451. https://doi.org/10.1080/00472336.2013.783966

Poullet, Y. (2011). e-Youth before its judges - Legal protection of minors in cyberspace. Computer Law \& Security Review, 27(1), 6-20. https://doi.org/10.1016/j.clsr.2010.11.011

Rasiah, R., Noh, A., \& Tumin, M. (2009). Privatising healthcare in Malaysia: Power, policy and profts. Journal of Contemporary Asia, 39(1), 50-62. https://doi.org/10.1080/00472330802506790

Rehman, J., \& Shahid, A. (2018). The asian yearbook of human rights and humanitarian law. Brill | Nijhoff. https://doi.org/10.1163/9789004346888 
Rosidah, Z. N. (2020). Coherence of the rules of sharia against Pancasila. Bestuur, 8(1), 40-52. https://doi.org/10.20961/bestuur.v8i1.42723

Saravanamuttu, J., \& Mohamad, M. (2020). The monetisation of consent and its limits: Explaining political dominance and decline in Malaysia. Journal of Contemporary Asia, 50(1), 56-73. https://doi.org/10.1080/00472336.2019.1569710

Singh, A. A., \& McKleroy, V. S. (2011). "Just getting out of bed is a revolutionary act": The resilience of transgender people of color who have survived traumatic life events. Traumatology, 17(2), 34-44. https://doi.org/10.1177/1534765610369261

Steele, J. (2013). "Trial by the press": An examination of journalism, ethics, and Islam in Indonesia and Malaysia. International Journal of Press/Politics, 18(3), 342-359. https://doi.org/10.1177/1940161213484588

Tapsell, R. (2013). The media freedom movement in Malaysia and the electoral authoritarian regime. Journal of Contemporary Asia, 43(4), 613-635. https://doi.org/10.1080/00472336.2013.765138

Teh, Y. K. (2002). Money politics in Malaysia. Journal of Contemporary Asia, 32(3), 338-345. https://doi.org/10.1080/00472330280000231

Tham, S. Y. (2017). Examining the shift to services: Malaysia and China compared. Journal of Contemporary Asia, 47(5), 728-751. https://doi.org/10.1080/00472336.2017.1310273

Vithiatharan, V., \& Gomez, E. T. (2014). Politics, economic crises and corporate governance reforms: Regulatory capture in Malaysia. Journal of Contemporary Asia, 44(4), 599-615. https://doi.org/10.1080/00472336.2014.923634

Weiss, M. L. (2013). Parsing the Power of "New Media" in Malaysia. Journal of Contemporary Asia, 43(4), 591-612. https://doi.org/10.1080/00472336.2012.759332

Zhang, M., Rasiah, R., \& Lee, J. K. Y. (2017). Navigating a Highly Protected Market: China's Chery Automobile in Malaysia. Journal of Contemporary Asia, 47(5), 774-791. https://doi.org/10.1080/00472336.2017.1345000 